Volume 5, Issue S1 (2020), pp. 30-34

Journal of School Administration Research and Development

ISSN: 2470-8496 Print/ ISSN: 2470-850X Online

ojed.org/jsard

\title{
Leading Through a Pandemic: Adaptive Leadership and Purposeful Action
}

\author{
Jack Bagwell \\ California State University, Northridge, USA
}

\begin{abstract}
As the coronavirus pandemic continues to reshape education, schools have had to adapt to a teaching reality that is increasingly more complex and uncertain. School leaders who take an adaptive leadership approach and leverage key leadership practices can support their schools in navigating the challenges of uncertain educational environments in adaptive ways.
\end{abstract}

Keywords: adaptive, coronavirus, leadership, schools

The rapid changes brought on by the coronavirus pandemic continue to pose extraordinary challenges for school leaders. The pandemic disrupted education for students as school closures occurred, and all teaching moved to a virtual space (Morgan, 2020). School leaders were forced to rethink the nature and degree of change necessary to support teachers and students in adopting new technologies and technical skills to navigate teaching and learning in a virtual environment (Kaden, 2020). Additionally, school leaders have seen a need to address the emotional well-being of teachers and students who are now themselves apprehensive and fearful about the future of schooling as the pandemic continues (Netolicky, 2020). School leaders are now being tested in ways that they have not been in the past. By adopting an adaptive approach to 
leadership, school leaders can build resiliency and capacity for their school communities to weather future disruptions cause by the pandemic.

\section{LITERATURE REVIEW}

\section{Lead Adaptively}

The coronavirus pandemic is rapidly redefining schooling and leadership. Distance learning and integrating technology are the realities that school leaders and teachers must contend with as schools reopen (Kaden, 2020). The speed of change will require school leaders to inspire school communities to adapt to needed change (Northouse, 2019). Adaptive work requires determining what currently requires change while rethinking how organizations will adapt and thrive in a new environment (Heifetz et al., 2009; Northouse, 2019). The path forward is for school leaders to learn their way through these challenges and lean on their colleagues to embrace different approaches than previously undertaken (Jefferies, 2017). The capacity for teachers and students to adapt during times of fast-paced change will hinge on school leaders staying learning-focused, engaging others in creative thinking, and launching innovative solutions. (Hsieh et al., 2014; Northouse, 2019).

\section{Build Resilience}

The challenge in building and maintaining relationships through the pandemic will be difficult. School leaders will be called upon to promote social-emotional well-being for their teachers and students as they cope with their own anxieties about family, health, and distance learning (Estep, 2013; Sommer et al., 2016). Now more than ever, school leaders must promote strategies to foster social connectedness during a time when many are experiencing social isolation and deep uncertainty. By creating opportunities for social connectedness through virtual platforms, school leaders can build resilience as individuals engage in collective sense-making about what is currently happening, while at the same time building individual capacity to cope during a crisis. As resiliency deepens, individuals become more resourceful, adaptive, and develop a sense of stability (Kuntz et al., 2017; Teo et al., 2017). In short, by building resilience and deepening social connections, school leaders will help their school communities to see the events unfolding as opportunities to challenge themselves to be adaptive and invest in building resilience by enlisting the leadership and support of others. 


\section{Distribute Leadership}

The adaptive challenges facing schools cannot be addressed by trait-driven or heroic approaches to leadership (Heifetz et al., 2009). By distributing leadership responsibilities, school leaders can lay the groundwork for collaboration, deepen relationships, and foster ownership and innovation through a process of collective problem solving (Kuntz et al., 2017; Raelin, 2016). Furthermore, adaptive leaders understand how trust, flexibility, and autonomy encourages organic expertise to flourish, which can motivate others to take creative approaches in tackling unforeseen challenges and needs as they arise (Kuntz et al., 2017). Generating innovative ideas and solutions is about increasing the diversity of ideas and shared learning for everyone. Diversity of ideas increases the likelihood of multi-perspective collaboration, which can lead to greater organizational adaptability and greater problem-solving capacity (Brown et al., 2020). By mobilizing individuals to collectively tackle challenges, school leaders have an opportunity to shift and alter existing practices and mindsets (Northouse, 2019; Yukl \& Mahsud, 2010).

\section{IMPLICATIONS}

The ongoing pandemic provides school leaders with the opportunity to reassess how technology integration through distance learning can be delivered equitably for all students while simultaneously addressing the tension between well-being and schooling demands for faculty and students. School leaders can demonstrate persistence and a growth mindset by modeling how to positively and productively respond to adversity and challenges. Moreover, school leaders can engage their faculty in job-embedded learning with technology and adaptive learning strategies and leverage social media to connect their faculty with other educators in sharing resources to broaden options for instructional delivery through distance learning. Finally, school leaders have the opportunity to build stronger ecosystems of support and partnership with community mental health agencies, social welfare organizations, local nonprofits, and businesses. By strengthening the social connectedness between schools and communities and addressing the challenges of teaching and learning in a virtual environment, school leaders can create schools that will emerge from the pandemic stronger and more vibrant.

As the pandemic continues to exacerbate inequalities across school systems, researchers should seek to understand the role of policymakers in addressing the 
disparities in student access to technology devices, broadband internet, and wireless network technology. Additionally, further research is needed to understand the technology capacity-building supports and skills needed by faculty as they adapt to learning different pedagogical practices for distance learning. Finally, researchers should explore how school leaders navigate distress and uncertainty during this pandemic while simultaneously supporting their faculty in embracing the need for change. Investigating how school leaders engage in adaptive leadership practice as they address the tensions and distress caused by change is timely.

\section{REFERENCES}

Brown, C., MacGregor, S., \& Flood, J. (2020). Can models of distributed leadership be used to mobilise networked generated innovation in schools? A case study from England. Teaching and Teacher Education, 94, Article e103101. https://doi.org/10.1016/j.tate.2020.103101

Estep, S. (2013). Crisis planning: Building enduring school-community relationships. The Delta Kappa Gamma Bulletin, 79(3), 13-20.

Heifetz R., Grashow, A., \& Linsky, M. (2009). The practice of adaptive leadership: Tools and tactics for changing your organization and the world. Harvard Business School Press.

Hsieh, M. H., Huang, H. Y., \& Seah, M. (2014). Leader driven organizational adaptation. Management Decision, 52(8), 1410-1432. https://doi.org/10.1108/MD-07-2013-0380

Jefferies, S. S. (2017). Adaptive leadership in a socially revolving world: A symbolic interactionist lens of adaptive leadership theory. Performance Improvement, 56(9), 46-50. https://doi.org/10.1002/pfi.21741

Kaden, U. (2020). COVID-19 school closure-related changes to the professional life of a K-12 teacher. Education Sciences, 10(6), 165. https://doi.org/10.3390/educsci10060165

Kuntz, J. R., Malinen, S., \& Näswall, K. (2017). Employee resilience: Directions for resilience development. Consulting Psychology Journal, 69(3), 223242. https://doi.org/10.1037/cpb0000097

Morgan, H. (2020). Best practices for implementing remote learning during a pandemic. The Clearing House: A Journal of Educational Strategies, Issues and Ideas, 93(3), 135-141. https://doi.org/10.1080/00098655.2020.1751480 
Netolicky, D. M. (2020). School leadership during a pandemic: Navigating tensions. Journal of Professional Capital and Community. Advance online publication. https://doi.org/10.1108/JPCC-05-2020-0017

Northouse, P. G. (2019). Leadership: Theory and practice (8th ed.). Sage Publishing.

Raelin, J. A. (2016). Imagine there are no leaders: Reframing leadership as collaborative agency. Leadership, 12(2), 131-158. https://doi.org/10.1177/1742715014558076

Sommer, S. A., Howell, J. M., \& Hadley, C. N. (2016). Keeping positive and building strength. Group \& Organization Management, 41(2), 172-202. https://doi.org/10.1177/1059601115578027

Teo, W. L., Lee, M., \& Lim, W. S. (2017). The relational activation of resilience model: How leadership activates resilience in an organizational crisis. Journal of Contingencies and Crisis Management, 25(3), 136-147. https://doi.org/10.1111/1468-5973.12179

Yukl, G., \& Mahsud, R. (2010). Why flexible and adaptive leadership is essential. Consulting Psychology Journal: Practice and Research, 62(2), 81-93. https://doi.org/10.1037/a0019835

JACK BAGWELL, EdD, is an Assistant Professor in the Educational Leadership \& Policy Studies Department, California State University, Northridge. His major research interests lie in the area of educational leadership in urban public schools. Email: jack.bagwell@csun.edu

Manuscript submitted: August 11, 2020

Manuscript revised: September 15, 2020 Accepted for publication: September 23, 2020 